\title{
Carbonation and $\mathrm{Cl}^{-}$Penetration Resistance of Alkali Silicate Impregnant of Concrete
}

\author{
Hun Song ${ }^{\dagger}$, Yong Sik Chu, and Jong Kyu Lee
}

Ceramic \& Building Materials Division, Korea Institute of Ceramic Engineering \& Technology, Seoul 153-801, Korea (Received September 18, 2008; Revised October 8, 2008; Accepted October 13, 2008)

\section{Silicate계 콘크리트 침투성 함침제의 탄산화 및 염해 저항성}

\author{
송 훈 $^{\dagger}$ 추용식 · 이종규 \\ 요업기술원 세라믹·건재본부 \\ (2008년 9월 18일 접수; 2008년 10월 8일 수정 ; 2008년 10월 13일 승인)
}

\begin{abstract}
Every concrete structure should continue to perform its intended functions such as to maintain the required strength and durability during its lifetime. Deterioration of the concrete structure, however, occurs more progressively from the outside of the concrete exposed to severe conditions. Main deteriorations in concrete structures result from carbonation, chloride ion attack and frost attack. Concrete can therefore be more durable by applying surface protection to increase its durability using impregnants, which are normally classified into two large groups in polymeric and silicate materials. Concrete impregnants are composed of silanes and alkali silicates (sodium, potassium and lithium silicate). Thus, this study is concerned with elevating the carbonation and $\mathrm{Cl}$ - penetration resistance of concrete structures by applying alkali silicate hydrophilic impregnants including lithium and potassium silicates. From the experimental test results, lithium and potassium silicates produced a good improvement in carbonation resistance and are expected to be used as hydrophilic impregnants of concrete structures.
\end{abstract}

Key words : Alkali Silicate, Impregnant, Hydrophilic, Carbonation, Durability

\section{1. 서 론}

콘크리트 구조물의 표면보호 공법은 표층부의 내구성 향상 또는 열화진행 억제의 효과를 목적으로 내구성능을 발휘하는 함침제를 표면으로부터 침투시켜 콘크리트 표충 부의 개질 및 기능을 부여하여 내구성능을 향상시킨다. 표. 면보호 공법은 콘크리트 표면 외관의 손실이 거의 없으 며 여타의 공법에 비해 공정이 작고 단기간에 시공이 가 능한 장점을 지니며 보호공빕 시공 후 시간의 경과에 따 른 열화에 따라 재시공 하는 경우 함침제를 재 도포하는 것으로 효과를 발휘할 수 있다. 표면보호 공법은 Carbonation, $\mathrm{Cl}^{-}$Penetration, Freezing and thawing, Alkali-silica reaction 등의 콘크리트 구조물의 열화를 억제·방지하는 대책으로서 유효하며 예방 보전을 전제로 하는 신설 구 조물의 적용 및 열화가 어느 정도 진행된 기존 구조물의 보수 혹은 기타의 보수공법과 겸용하여 적용하는 것이 가 능하다 ${ }^{1,2)}$.

시판되는 침투성 함침제의 주성분은 Silane계 및 Silicate 계로 구분할 수 있으며 기대성능 및 적용효과는 Table 1

\footnotetext{
${ }^{\dagger}$ Corresponding author : Hun Song

E-mail : songhun@kicet.re.kr

Tel : +82-2-3282-7830 Fax : +82-2-3282-2430
}

과 같다. Silane계 함침제는 Alkyl alkoxy silane monomer 및 Oligomer가 이용되며 이들을 물 혹은 유기용제에 희 석한 침투성 함침제를 통칭하는 것으로 콘크리트 표면이 나 균열부에 수 $\mathrm{mm}$ 의 범위에 걸쳐 함침하며 Hydrophobic surface를 형성하여 물 혹은 $\mathrm{Cl}^{-}$등의 열화인자 침입을 방 지한다. Silane계는 내구성능 면에서 Silicate계에 비해 우 수하나 유성 오염원에 의한 자기세정, 도포 시공성능 및 가격에서 불리하다 ${ }^{4,6,7)}$.

Silicate계는 Sodium silicate 혹은 Lithium 및 Potassium silicate를 주성분으로 하는 수용액이며 탄산화한 부분의 알칼리 부여와 성능저하가 예상되는 부위의 강화 등 콘 크리트 성능회복에 주로 이용된다. Silicate계는 콘크리트 에의 침투성을 항상시키기 위해 계면활성제나 콘크리트 중의 Calcium hydroxide와의 반응을 개선하기 위한 반응 촉진제, 경화제 등이 첨가된다. Sodium silicate는 가격이 저렴하여 널리 사용되나 강우에 의해 $\mathrm{Na}$ 가 용출되어 콘 크리트 표면을 오염시키고 탄산화가 급격히 진전되는 Alkali efflorescence가 발생하기 쉅다. Lithium silicate 및 Potassium silicate는 미적기능이 강조되어 마감면이 그대 로 노출되는 컬러콘크리트 등의 고기능을 요구하는 경우 적용되며 콘크리트 구조물 외관의 손상없이 비교적 간편 하게 시공할 수 있으며 미세기공을 완전하게 메우지 않 
Table 1. Effectiveness of Concrete Impregnants and Its Applications $^{1)}$

\begin{tabular}{lccc}
\hline & \multirow{2}{*}{ Silane } & \multicolumn{2}{c}{ Silicate } \\
\cline { 3 - 4 } & & Lithium & Sodium \\
\hline Carbonation & $\triangle$ & $\triangle$ & $\bigcirc$ \\
Cl Penetration & & - & $\bigcirc$ \\
Freezing and thawing & $\triangle$ & - & $\triangle$ \\
Chemical attack & - & - & - \\
Alkali-silica reaction & $\triangle$ & $\triangle$ & - \\
Spalling resistance & $\triangle$ & - & $\triangle$ \\
\hline
\end{tabular}

$\bigcirc$ : Excellent, $\triangle$ : Good

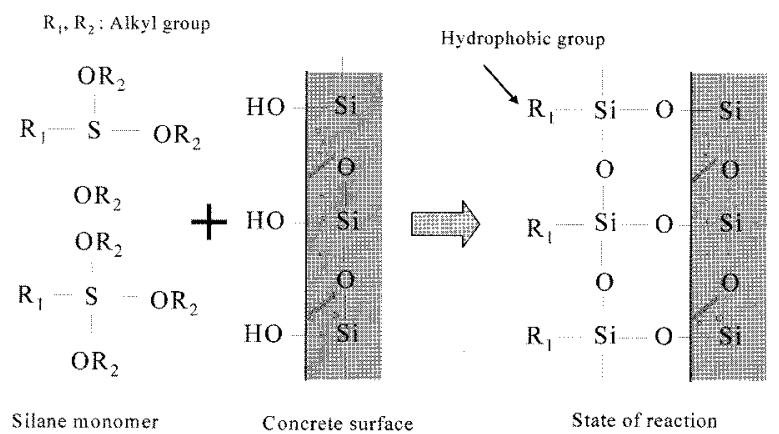

(Silane)

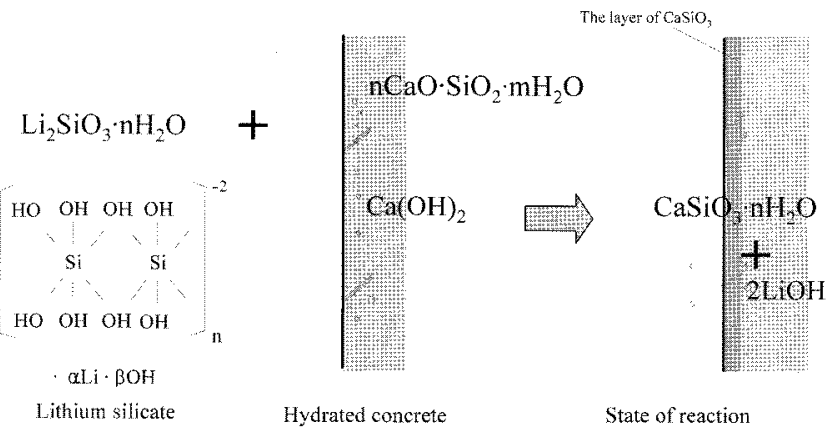

(Silicate)

Fig. 1. Reaction mechanism of concrete impregnants.

으므로 콘크리트 본래의 호흡성을 손상하지 않는다. ${ }^{1,5,8,9)}$ 본 연구에서는 콘크리트 침투성 함침제로서 Lithium silicate 및 Potassium silicate를 사용하여 노출 및 컬러콘 크리트 등의 고기능성이 요구되는 건축물에 적용이 가능 하고 부유 오염원 제거를 위한 친수성 표면형성과 상온
경화가 가능한 콘크리트 표면 함침제를 제조하였다. 또한 제조된 함침제의 건축물 적용을 위한 탄산화 저항성 및 $\mathrm{Cl}^{-}$침투저항성, 동결융해 저항성 등의 내구성능에 대해 검토하고자 한다.

\section{2. 실험 방법}

\section{1. 출발원료 분석}

콘크리트 침투성 함침제의 출발원료로는 Lithium silicate 및 Potassium silicate를 사용하였으며 물리·화학적 조성은 Table 2와 같다. Lithium silicate는 Potassium silicate 및 Sodium silicate와는 달리 안정성이 높고 건조된 피막의 내 수성이 우수한 특징을 지닌다. 또한, Potassium silicate는 Sodium silicate와 유사한 성질과 용도를 가지지만 Alkali efflorescence의 발생이 적어 콘크리트 자체 마감이 되는 경우 사용이 용이하다.

Lithium silicate는 Potassium silicate는 콘크리트 표층부 에의 침투성능 향상 및 점도조절을 위해 $\mathrm{SiO}_{2}$ 함량을 조 절하였고, $\mathrm{Al}$ 계 경화제를 중량비로 $0.15 \%$ 를 첨가하여 침 투성 함침제를 제조하였다. 제조된 침투성 함침제는 $\mathrm{SiO}_{2}$ 의 함량은 $5,10,20 \%$ 이며 원료의 배합표는 Table 3 과 같 다. 모르타르 및 콘크리트 바탕에의 침투성 함침제의 사 용량은 $0.3 \mathrm{~kg} / \mathrm{m}^{2}$ 이며 붓과 롤러를 이용하여 도포하였다.

\section{2. 시험체의 제작 및 시험방법}

함침제의 표면특성을 측정하기 위한 모르타르 시험체 는 KS F 5105의 시멘트 모르타르의 제작방법에 준하여 제작하였으며 시멘트 강도 시험용 표준사를 사용하였다. 시멘트와 표준사의 무게비는 $1: 2.45$ 이며 $\mathrm{W} / \mathrm{C}$ 는 $48.5 \%$ 이 다. 함침제의 표면특성은 접촉각 시험기를 사용하여 측정 하였다. 모르타르나 콘크리트는 배합조건이나 강도에 따 라 다르지만 약 $10 \sim 20 \%$ 의 기공을 가지고 있기 때문에 표면에 물이 닿으면 내부로 흡수되어 측정할 수 없는 것 이 일반적이다. 하지만 조직이 치밀한 고강도 콘크리트나 표면처리한 바탕면의 경우 표면에서 접촉각을 측정할 수 있는데, 본 시험에서도 함침제의 표면특성을 평가하기 위 한 방편으로 제작된 모르타르 시험체의 표면을 다시 시 멘트 페이스트로 기공을 메우는 바탕처리를 실시하였다. 접촉각의 측정은 자동 접촉각 측정이 가능한 접촉각 시 험기를 사용하였으며 약 $30 \mathrm{sec}$ 간 $1 \mathrm{sec}$ 간격으로 측정하 였다.

Table 2. Physical and Chemical Properties of Start Materials

\begin{tabular}{lcccccccc}
\hline & Symbol & Color & $\begin{array}{c}\text { Silica } \\
\text { content }(\%)\end{array}$ & $\begin{array}{c}\mathrm{Li}_{2} \mathrm{O} \\
\text { content }(\%)\end{array}$ & $\begin{array}{c}\mathrm{K}_{2} \mathrm{O} \\
\text { content }(\%)\end{array}$ & $\begin{array}{c}\text { Mole } \\
\text { ratio }\end{array}$ & $\begin{array}{c}\text { Density } \\
(\mathrm{g} / \mathrm{ml})\end{array}$ & $\begin{array}{c}\text { Viscosity } \\
\left(\mathrm{cps} \text { at } 20^{\circ} \mathrm{C}\right)\end{array}$ \\
\hline Lithium silicate & LS & water-white & 21.6 & 1.37 & - & 7.93 & 1.17 & 27.2 \\
Potassium silicate & PS & water-white & 20.0 & - & 6.50 & 4.36 & 1.20 & 8.5 \\
\hline
\end{tabular}


Table 3. Mix Proportions of Concrete Impregnants

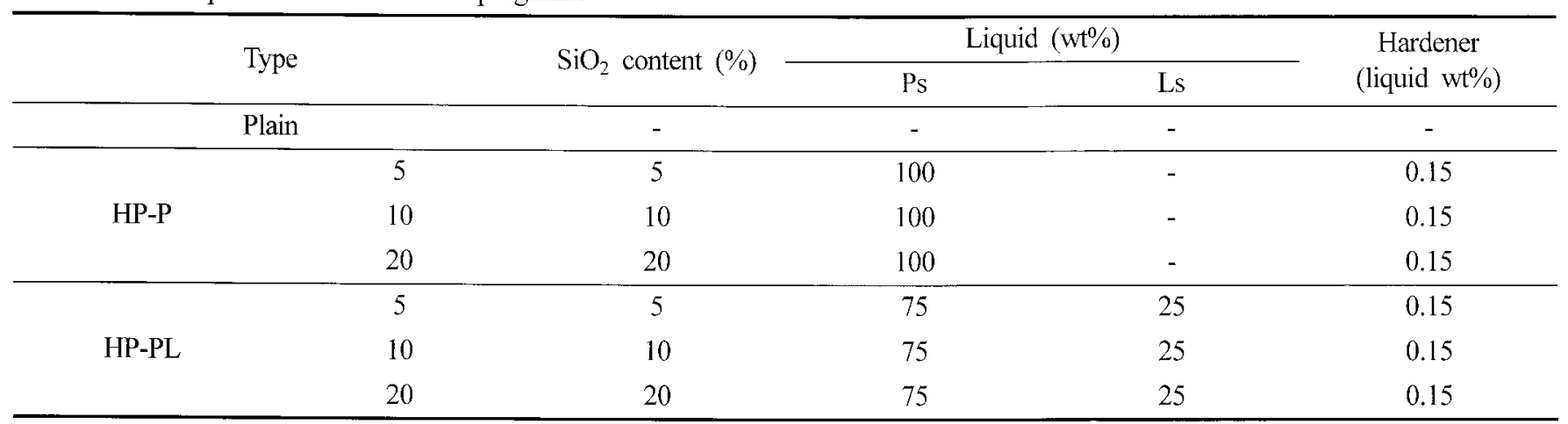

Table 4. Mix Proportion of Plane Concrete

\begin{tabular}{|c|c|c|c|c|c|c|c|c|c|c|}
\hline & \multirow{2}{*}{$\mathrm{W} / \mathrm{C}(\%)$} & \multirow{2}{*}{ S/a $(\%)$} & \multicolumn{4}{|c|}{ Unit Weight $\left(\mathrm{kg} / \mathrm{m}^{3}\right)$} & \multirow{2}{*}{$\begin{array}{c}\text { AE agent } \\
\left(C^{* \%} \%\right)\end{array}$} & \multirow{2}{*}{$\begin{array}{l}\text { Slump } \\
(\mathrm{cm})\end{array}$} & \multirow{2}{*}{$\begin{array}{c}\text { Air content } \\
(\%)\end{array}$} & \multirow{2}{*}{$\begin{array}{c}\text { Compressive } \\
\text { strength } \\
(\mathrm{MPa})\end{array}$} \\
\hline & & & W & C & $\mathrm{S}$ & $\mathrm{G}$ & & & & \\
\hline Concrete & 54.3 & 47.5 & 157 & 289 & 888 & 989 & 0.9 & 11 & 4.7 & 24 \\
\hline
\end{tabular}

Table 5. Contact Angles of Concrete Impregnants

\begin{tabular}{cccccccc}
\hline & Plain & HP-P5 & HP-P10 & HP-P20 & HP-PL5 & HP-PL10 & HP-PL20 \\
\hline Mortars & $83 \sim 120^{\circ}$ & $65 \sim 105^{\circ}$ & below $30^{\circ}$ & below $30^{\circ}$ & $65 \sim 95^{\circ}$ & below 30 & below 30 \\
\hline
\end{tabular}

내구성능 평가를 위한 콘크리트 시험체는 KS F 2403 의 콘크리트강도 시험용 공시체 제작방법에 준하여 제작 하였다. 시험체는 건축물에 일반적으로 적용되는 호칭강 도 $24 \mathrm{MPa}$ 의 보통 콘크리트이며 잔골재는 세척사를, 굵 은골재는 최대치수 $20 \mathrm{~mm}$ 의 골재를 사용하였다. 콘크리 트 시험체의 $\mathrm{W} / \mathrm{C}$ 는 $54.3 \%$ 이며 단위수량은 $157 \mathrm{~kg} / \mathrm{m}^{3}$ 이 며 배합표는 Table 4와 같다.

탄산화 저항성, $\mathrm{Cl}^{-}$침투저항성 및 동결응해 저항성은 직경 $100 \mathrm{~mm}$ 높이 $200 \mathrm{~mm}$ 의 원형 콘크리트 시험체를 사용 하여 측정하였다. 탄산화 저항성 시험은 $20,60 \%$ R.H., $10 \%$ 의 $\mathrm{CO}_{2}$ 조건의 촉진 탄산화 챔버를 사용하여 실시하 였으며, $1 \%$ Phenolphthalein 용액을 분무하여 백색을 발하 는 부분을 탄산화 깊이로 측정하였다. 또한, $\mathrm{Cl}^{-}$침투저항 성 시험은 20 의 $2.5 \%$ 용액 중에 14 일간 침적한 후, $0.1 \%$ Fluorescein sodium 용액과 $0.1 \mathrm{~N} \mathrm{AgNO}_{3}$ 용액을 분무하여 형광을 발하는 부분까지를 $\mathrm{Cl}^{-}$침투깊이로 산정하였다 ${ }^{3)}$. 동결융해 저항성 시험은 $\mathrm{KS} \mathrm{F} \mathrm{2456에} \mathrm{준하여} \mathrm{동결융해}$ 챔버를 사용하여 실시하였으며 동결온도는 $-18^{\circ} \mathrm{C}$, 융해 온도는 $4^{\circ} \mathrm{C}$ 로 유지하였다.

\section{3. 결과 및 고찰}

\section{1. 표면접촉각 및 점도}

$\mathrm{HP}-\mathrm{P}$ 및 $\mathrm{HP}-\mathrm{PL}$ 계 콘크리트 침투성 함침제의 모르타르 바탕에의 접촉각 시험결과는 Table 5와 같다. 시멘트 페 이스트로 바탕처리 한 모르타르 표층에서의 접촉각은
$83 \sim 120^{\circ}$ 으로 나타났다. 모르타르 바탕면의 경우 어느 정 도의 미세한 표면 요철로 인해 부위에 따라 접촉각은 약 간 다르게 나타난다. 콘크리트 표면의 친수성 및 소수성 은 물에 의한 접촉각으로서 평가하는데 친수성의 경우 $30^{\circ}$ 이하를, $100^{\circ}$ 이상의 경우 소수성으로 평가한다. 자기 세정이 가능한 방오성능을 지니는 표면은 친수성 및 소 수성 표면이 모두 적용될 수 있는데 친수성의 경우 -OH 기 및 $-\mathrm{COOH}$ 기에 의한 오염물 제거와 소수성의 경우 미 세표면 요철에 의한 Lotus effect를 이용한 것이다. 일반 적으로 건축물에서의 자기세정은 내구성의 측면에서 유 리한 Silane계 함침제를 이용하여 소수성 표면을 형성하 는 방법과 $\mathrm{TiO}_{2}$ 를 이용하여 광분해에 의한 오염물 제거 방법이 주로 사용된다. ${ }^{1)}$ 본 실험에서도 실리카 함량이 $5 \%$ 인 HP-P5 및 HP-PL5의 경우 접촉각은 $65 \sim 105^{\circ}$ 및 $65 \sim 95^{\circ}$ 이었으나 실리카 함량이 $10 \%$ 이상인 시험체의 경 우 $30^{\circ}$ 이하의 접촉각을 나타내 오염물 제거가 가능한 친 수성 표면을 형성하였다.

HP-P 및 HP-PL계의 점도를 Fig. 2에 나타내었다. 침투 성 함침제는 실리카 함량의 증가에 따라 점도도 증가하 는 경향을 보였고 점도의 차도 크게 나타났다. 또한 HP$\mathrm{P}$ 및 HP-PL계의 점도는 온도가 증가함에 따라 감소하는 경향을 보였고 실리카 함량이 높을수록 온도에 따른 변 화도 크게 나타났다. 침투성 함침제 HP-PL20의 점도가 가장 높게 나타났는데 이는 출발원료인 Lithium silicate의 점도가 높음에 기인한다. 침투성 함침제의 점도는 콘크리 트 표층에의 침투깊이에 영항을 미치며 점도가 작을수록 

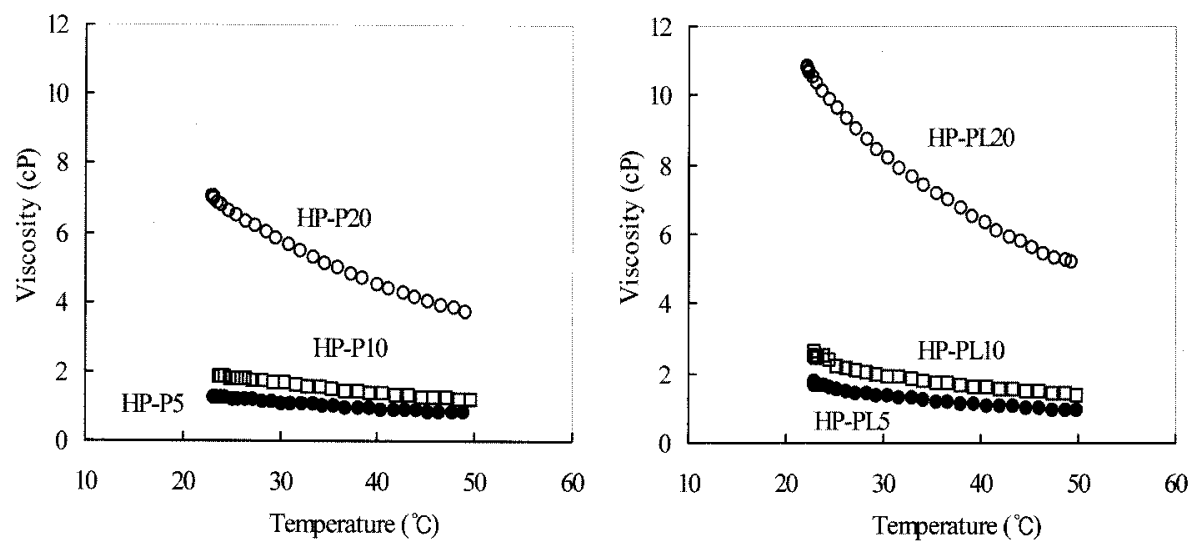

Fig. 2. Temperature vs. viscosities of concrete impregnants.

작업성 및 침투성능이 우수하나 기대되는 내구성능은 저 하하므로 콘크리트 표층부의 세공 및 미세한 균열에 함 침하기 쉬운 조건으로 점도를 조절하거나 적합한 선택이 필요하다.

\section{2. 내구특성 평가}

HP-P 및 HP-PL 시험체의 촉진 탄산화 시험결과를 Fig. 3 및 Table 5에 나타내었다. 촉진 탄산화 시험결과 함침제 를 사용하지 않은 Plain 시험체의 경우 2주 경과 후 약 $8 \mathrm{~mm}, 4$ 주 경과 후 약 $10 \mathrm{~mm}, 8$ 주 경과 후 $15 \mathrm{~mm}$ 정도 의 $\mathrm{CO}_{2}$ 에 의한 탄산화 깊이를 보였다. 침투성 함침제를 도포한 경우 HP-P5 및 HP-PL5 시험체를 제외하고 Plain 시험체 보다 탄산화의 진행이 적어 함침제의 효과를 확 인할 수 있었다. HP-P20 및 HP-PL20 시험체의 경우 2주 경과 후의 탄산화 깊이는 모두 $4 \mathrm{~mm}$ 이하로 나타났으며 이와 같은 결과는 침투성 함침제가 콘크리트 내부의 $\mathrm{Ca}(\mathrm{OH})_{2}$ 와 반웅하여 $\mathrm{CaSiO}_{3}$ 의 결정층을 생성하여 구체강 화 및 열화방지의 효과를 발휘한 것으로 특히, 탄산화 초 기에 유효하였고 이에 따라 구조물의 수명을 고려한 유 지관리의 측면에서 매우 유리할 것으로 판단된다.

또한, HP-P 및 HP-PL 시험체 모두 실리카 함량이 높을 수록 탄산화의 진행정도가 작아지는 경향을 보였다. 침투 성 함침제는 $\mathrm{nm}$ 크기의 입자로 쉽게 콘크리트의 모세관 공극을 통하여 침투하고 $\mathrm{Ca}(\mathrm{OH})_{2}$ 와 반응하여 고화하며 콘크리트의 Capillary Voids를 충전하지만 실리카 함량이 작은 HP-P5 시험체의 경우는 모세관 충전의 호과가 작아 탄산화 저항성능을 기대할 수 없다. 하지만 실리카 함량 이 높을수록 모세관 충전에 의한 효과는 기대할 수 있으 나 반대로 점도의 증가로 인한 콘크리트에의 침투성능 저 하가 예상되므로 초벌시의 침투를 위한 점도 조절과 내 구성능 향상을 위한 적절한 점도 유지도 필요하다. 본 실 험에 적용된 침투성 함침제의 경우 $20 \mathrm{cP}$ 이하의 저 점도 로 콘크리트 표층부로의 흡수가 용이하여 탄산화에 대해 비교적 양호한 저항성능을 기대할 수 있었다.
HP-P 및 HP-PL 시험체의 $\mathrm{Cl}^{-}$침투저항성 시험결과를 Fig. 4 및 Table 6에 나타내었다. $\mathrm{Cl}^{-}$침투저항성 시험결 과 함침제를 사용하지 않은 Plain 시험체의 경우 2주 경 과 후 약 $10 \mathrm{~mm}, 4$ 주 경과 후 약 $13 \mathrm{~mm}$ 의 $\mathrm{Cl}^{-}$침투깊이 를 보였다. $\mathrm{Cl}^{-}$침투깊이도 침투성 함침제를 도포한 시험 체가 Plain 시험체 보다 우수한 결과를 보였다. 또한, HP$\mathrm{P}$ 및 HP-PL 시혐체 모두 실리카 함량이 높을수록 $\mathrm{Cl}^{-}$침 투깊이의 진행정도가 작아지는 경향을 보였다. HP-P 및 $\mathrm{HP}-\mathrm{PL}$ 시험체의 $\mathrm{Cl}^{-}$침투저항성은 2 주차에서는 거의 유사 하였으며 4주차에서는 HP-PL 시험체의 저항성이 약간 우

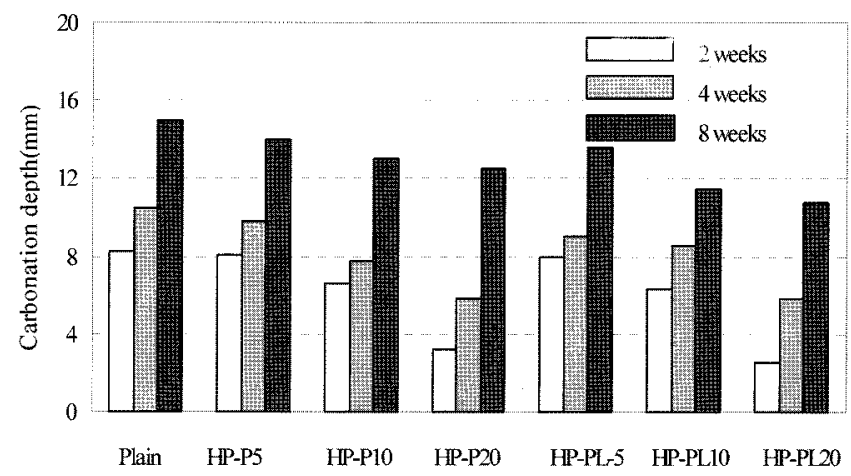

Fig. 3. Carbonation depths of concrete impregnants.

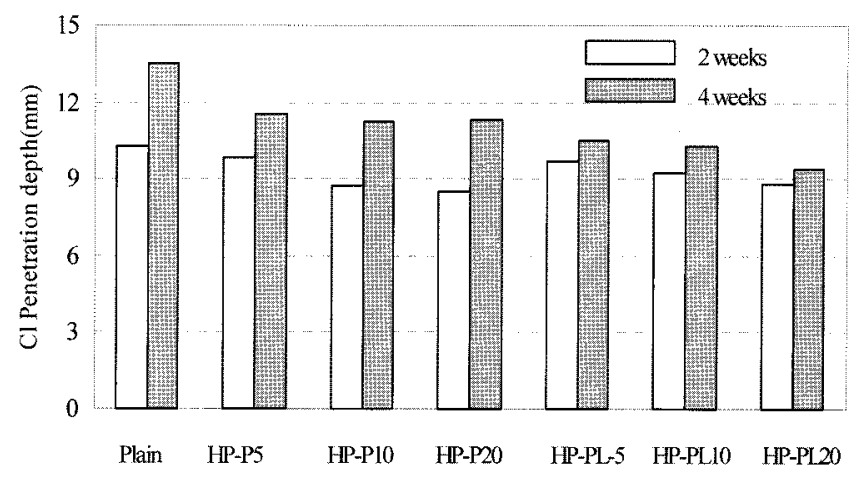

Fig. 4. $\mathrm{Cl}^{-}$Penetration depths of concrete impregnants. 
Table 5. Cross-sections of Concrete Impregnants after Carbonation Tests

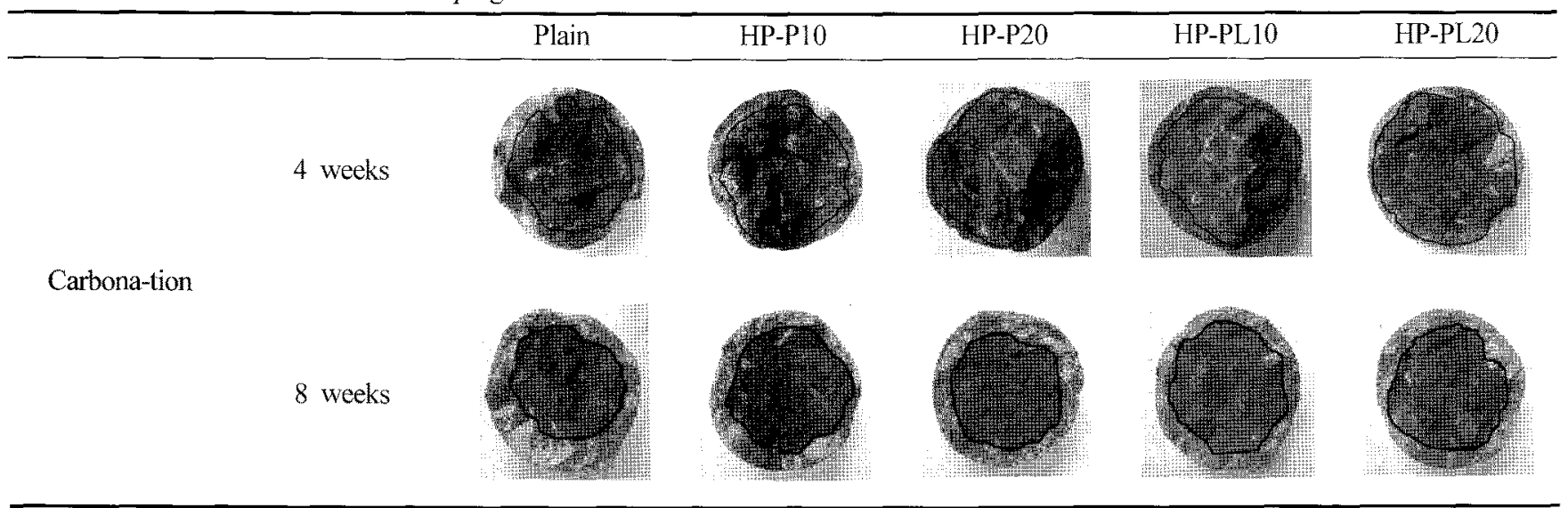

Table 6. Cross-sections of Concrete Impregnants after $\mathrm{Cl}$ Penetration Tests

\begin{tabular}{|c|c|c|c|c|c|c|}
\hline & & Plain & HP-P10 & HP-P20 & HP-PL10 & HP-PL20 \\
\hline $\mathrm{Cl}$ Penetrat-ion & 4 weeks & & & & & \\
\hline
\end{tabular}
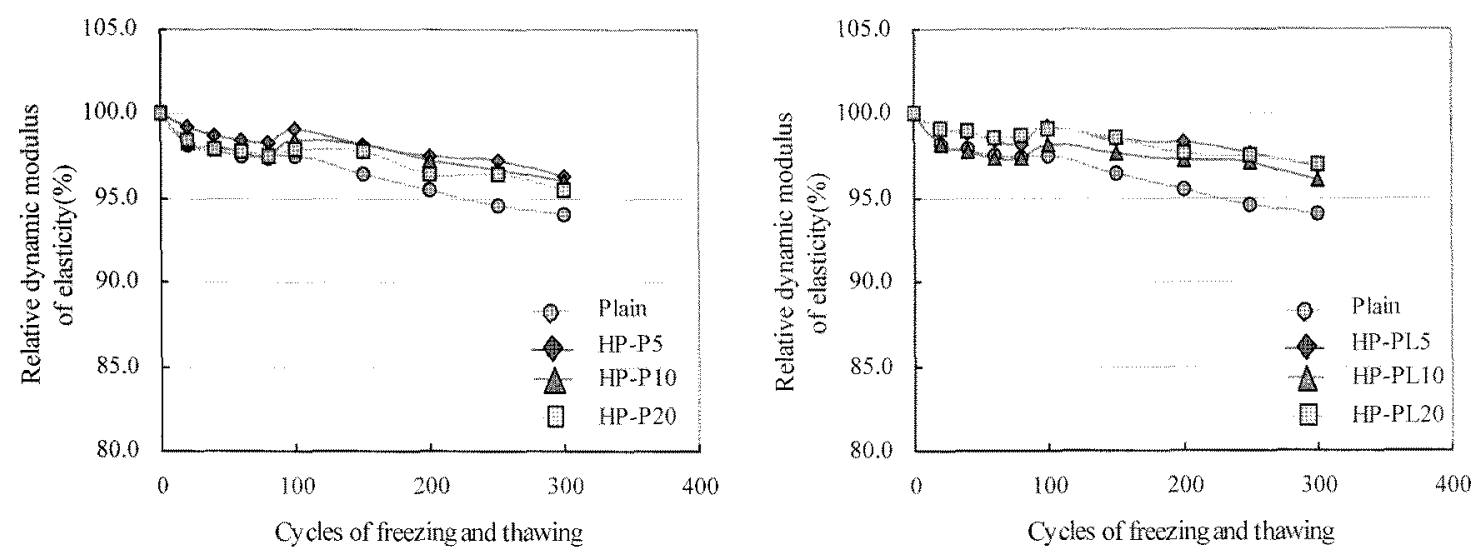

Fig. 5. Cycles of freezing and thawing vs. relative dynamic modulus of elasticity of concrete impregnants.

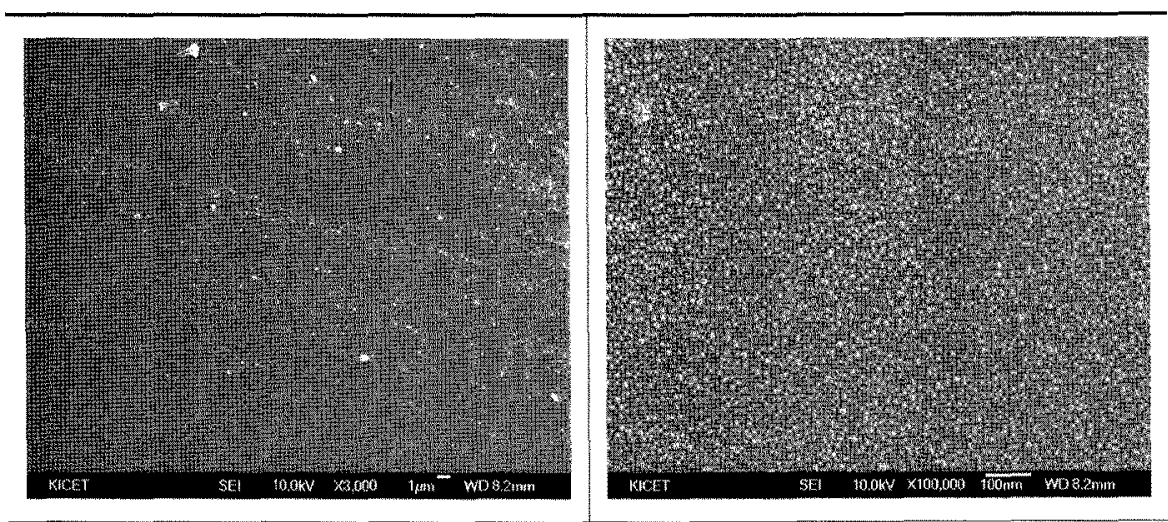

Fig. 6. $\mathrm{SiO}_{2}$ Coated in concrete surface structure with HP-PL. 
수한 결과를 보였다. 이는 Lithium silicate가 Potassium silicate 보다 안정성이 높고 피막의 내수성이 약간 우수한 결과에서 기인한다.

하지만, 전체적으로 촉진 탄산화 시험 결과와는 달리 그 차가 크지 않았으며 결과값 또한 유사하였다. 이는 침 투성 함침제의 친수성에 의한 $-\mathrm{OH}$ 기의 지속적인 소실과 내수성 저하에따른 결과이다. 본 시험의 HP-P 및 HP-PL 시험체도 자기세정에 의한 도시의 유성 오염원을 원활히 제거하기 위하여 기존의 Silicate계 함침제에 기능성을 부 여한 것으로 지속적인 효과를 위한 내수성 향상과 효과 를 극대화하기 위한 시공방법의 적용도 필요 불가결하다. $\mathrm{HP}-\mathrm{P}$ 및 HP-PL 시험체의 동결융해 저항성 시험결과를 Fig. 5에 나타내었다. 동결융해 저항성은 상대동탄성계수 로서 평가가 가능하며, 상대동탄성계수는 cycle수의 경과 에 따라 점차적으로 감소하는 경향을 보였다. 300 cycle 후의 Plain 시험체의 상대동탄성계수는 약 94\%를 나타냈 으며, HP-P 및 HP-PL 시험체의 경우 $95 \%$ 이상으로 Plain 시험체 보다 약간 높은 결과를 보였다. 전체적으로 시험 체에 종류에 상관없이 $90 \%$ 이상의 앙호한 값을 보였는 데 이는 콘크리트 제조시 $\mathrm{AE}$ 제 사용과 이에 따른 연행 된 공극 증가로 시험체 자체가 동결융해에 대한 저항성 이 큰 것에서 기인한다.

Fig. 6은 FE-SEM에 의한 조직관찰 결과로서 실리카 층 의 형성과 $\mathrm{nm}$ 크기의 실리카를 확인할 수 있었다. 경화 된 콘크리트를 구성하는 $\mathrm{nCaO}-\mathrm{SiO}_{2}-\mathrm{H}_{2} \mathrm{O}$ (이하 C-S-H) 및 $\mathrm{Ca}(\mathrm{OH})_{2}$ 의 간극 크기는 약 $1 \mathrm{~nm}$ 및 $1 \mathrm{um}$ 이며, 경화된 콘 크리트의 가장 작은 공극인 Capillary Voids도 $0.1 \mathrm{um}$ 크 기이므로 내부로의 함침이 용이하다. 연행 공극이나 균열 부는 $100 \mathrm{um} \sim 1 \mathrm{~mm}$ 의 크기이므로 침투성 함침제의 도포 에 따라 내부로 침투하여 공극의 일부가 메워지는 효과 를 발휘한다. 또한 전술한 바와 같이 내부로 침투된 함침 제는 $\mathrm{CaSiO}_{3}$ 의 결정충을 생성하여 $\mathrm{CO}_{2}$ 나 $\mathrm{Cl}^{-}$침입을 차 단하여 구조물의 내구성을 향상시킨다.

\section{4. 결 론}

Lithium 및 Potassium silicate를 이용하여 제조한 콘크리 트 함침제는 내부로 침투하여 콘크리트 표층에 친수성을 부여하고, 탄산화, $\mathrm{Cl}^{-}$침투저항성, 동결융해 등의 성능저 하가 예상되는 부위의 강화 등 콘크리트 성능회복에 이 용이 가능한 본 연구의 결과를 정리하면 다음과 같다.

1. HP-P 및 HP-PL계 침투성 함침제는 $30^{\circ}$ 이하의 표면 접촉각을 나타내 친수성 표면을 형성하였다. 실리카 함량 이 작을수록 사용온도가 높을수록 점도도 작았으며 침투 깊이 및 내구성능 향상에 유효한 함침제의 실리카 함량 은 $10 \sim 20 \%$ 가 적절하다.
2. HP-P 및 HP-PL계 침투성 함침제의 적용에 따라 탄 산화 저항성, $\mathrm{Cl}^{-}$침투 저항성 및 동결융해 저항성이 향 상되어 내구성능 개선에 유리하다. 또한, Lithium silicate 를 $25 \mathrm{wt} \%$ 흔합하여 사용하는 경우 내수성 개선에 약간 유리하다.

3. HP-P 및 HP-PL계 침투성 함침제의 적용에 따라 탄 산화 열화 요인에 대해 초기 개선효과가 크게 나타나 재 도포 시기나 방법 등을 조절한다면 콘크리트 구조물의 지 속적인 내구성능 확보가 가능하다.

4. Silicate계 침투성 함침제는 기 탄산화된 부위에 도포 하여 Alkali를 부여하고 내구성능 항상을 기대할 수 있으 며 탄산화에 대해 효과가 크다. 하지만 내구성에 대한 보 강과 침투깊이에 따른 구체강화 효과나 현장 적용성에 대 해서는 지속적인 연구가 필요하다.

\section{Acknowledgment}

본 연구는 요업기술원 정책연구사업의 일환으로 수행 되었으며, 이에 감사드립니다.

\section{REFERENCES}

1. JSCE, Recommendation for Concrete Repair and Surface Protection of Concrete Structures(in Jpn.); pp. 10-19, Jpn. Soc. Civil Eng., 2005.

2. AIJ, Japanese Architectural Standard Specification(in jpn.); JASS 18 Paint Work, pp. 39-80, Archi. Insti. Jpn., 1998.

3. AIJ, Test Methods for Quality Control and Maintenance of Reinforced Concrete Buildings(in Jpn.); pp. 99-141, Archi. Insti. Jpn., 2007.

4. T. Y. Jang, J. S. Kim, and J. Yon, "Maintenance and Coating Method for Exposed Concrete(in Kor.)," Spec. Arti. Kor. Conc. Insti., 13 [4] 54-61 (2001).

5. JCI, Repair Methods of Concrete Structures(in Jpn.); Committee Report, pp. 1-8, Jpn. Conc. Insti., 1996.

6. K. K. Kim, M. S. Paik, I. M. Song, Y. D. Lee, and S. J. Jung, "Performance Evaluation of Concrete Surface Painted on Types Silicic Lithium(in Kor.)," J. Archi. Insti. Kor, 23 [11] 127-34 (2007).

7. S. K. Oh, S. D. Ahn, and S. M. Shim, "Effect of Silane Solution of Capillary Coating Type as Protection Agent of Absorption for the Durability Improvement in Concrete Surface Layer(in Kor.)," J. Archi. Insti. Kor, 17 [12] 149-58 (2001).

8. I. D. Hwang, W. J. Lee, H. N. Youm, and Y. J. Chung, "The Evaluation on n-Octyl Ethoxy Silane as a Water Repellent of Concrete(in Kor.)," J. Kor. Ceram. Soc., 37 [12] 1172-77 (2000).

9. Ralph K, Iler, The Chemistry of Silica; pp. 117-121, A Wiley-Intersci. Pub., New York, 1979. 